\title{
Prevalence and level of infection by endoparasites in different categories of sheep in the Western Amazon
}

\section{Prevalência e nível de infecção por endoparasitas em diferentes categorias de ovinos na Amazônia Ocidental}

\author{
Antonio José Souza da Silva'; Rafael Ferreira da Silva1; Antonia Valcemira \\ Domingos de Oliveira2*; Luiz Eduardo Barreto de Souza3; Mariene Santos de \\ Araújo Souza ; Dayana Alves da Costa ${ }^{5}$
}

\section{Highlights}

The prevalence of coccidial strongholds and cestodes - Moniezia sp.

Lambs were most affected by nematode worms infection.

Brown, single and brown sheep had low OPG.

The highest infection intensity was of gilts, exceeding acceptable rates.

\begin{abstract}
This study aimed to understand the epidemiology of the main gastrointestinal endoparasites affecting sheep raised in the municipality of Sena Madureira, Acre, Brazil. A total of 178 fecal samples were collected from sheep raised in an extensive system of 10 farms. The samples were grouped into lambs, ewe lambs, lambing ewes, ewes, and rams for laboratory analysis by the flotation technique for counting eggs per gram of feces (EGF), oocysts of Eimeria sp., and presence of eggs of Moniezia sp. The analyzed variables consisted of the prevalence of nematodes, cestodes, and coccidia and intensity of strongylid and coccidium infection by quantification (mean $\pm \mathrm{SE}$ ) of eggs and oocysts. Prevalence data were compared by the chisquare test and intensity of infection (mean \pm SE) by the Scott-Knott test (SAEG 9.1), both with $P<0.05$. The overall prevalence was $77.6 \%$, reaching $64.15 \%$ for strongylids, $36.2 \%$ for coccidia, and $8.81 \%$ for cestodes (Moniezia sp.). Ewes had the lowest prevalence (52.5\%), while lambs had a prevalence of 95.5\%,

1 Graduated in Zootechnician from the Instituto Federal de Educação, Ciência e Tecnologia do Acre, IFAC, Câmpus Sena Madureira Acre, AC, Brazil. E-mail: antoniosouza.silva@hotmail.com; rafaelferreira.ac@gmail.com

2 Student of the Stricto Sensu Graduate Program, at the Master's level in Health and Sustainable Animal Production in the Western Amazon, Rio Branco, Acre, Brazil, Universidade Federal do Acre, UFAC, AC, Brazil. E-mail: valcemira@ hotmail.com

3 Prof. Dr., Undergraduate Course in Zootechnics, Instituto Federal de Educação, Ciência e Tecnologia do Acre, IFAC, Campus Sena Madureira Acre, AC, Brazil. E-mail: luiz.souza@ifac.edu.br

4 Graduated in Zootechnics, Instituto Federal de Educação, Ciência e Tecnologia do Acre, IFAC, Câmpus Sena Madureira Acre, AC, Brazil. E-mail: ene.santos20@hotmail.com

${ }^{5}$ Prof $^{a} \mathrm{Dr}^{\mathrm{a}}$, Undergraduate Course in Zootechnics, Instituto Federal de Educação, Ciência e Tecnologia do Acre, IFAC, Campus Sena Madureira Acre, AC, Brazil. E-mail: dayana.costa@ifac.edu.br

* Author for correspondence
\end{abstract}

Received: Oct. 09, 2020 - Approved: Mar. 11, 2021 
not differing from the others $(P<0.05)$. The intensity of infection by nematodes showed that lambs had the highest EGF compared to ewes, with values of $1297 \pm 270$ and $232 \pm 79$, respectively. The categories lambing ewes, ewes, and rams presented an average EGF below what is indicated for treatment with drugs. The highest intensity of infection was observed for ewe lambs (5859 \pm 3648$)$, exceeding acceptable rates. Sheep raised in Sena Madureira has a high prevalence for verminosis by strongylids and a low prevalence for coccidiosis and cestodiasis. Young animal categories present a high health risk for endoparasitoses, and management measures that collaborate with the prophylaxis and control of these diseases should be adopted.

Key words: Eimeriosis. EGF. Parasitism. Verminosis.

\section{Resumo}

Objetivou-se conhecer a epidemiologia dos principais endoparasitas gastrointestinais que acometem ovinos criados no município de Sena Madureira-Acre. Foram coletadas 178 amostras fecais de ovinos criados em sistema extensivo de 10 propriedades rurais. As amostras foram agrupadas: cordeiros, marrãs, ovelhas paridas, ovelhas solteiras e reprodutores para análise laboratorial pela técnica de flutuação para a contagem de ovos por grama de fezes (OPG), oocistos de Eimeria sp. e presença de ovos de Moniezia sp. As variáveis analisadas foram: prevalência dos nematódeos, cestódeos e coccídios; intensidade de infecção por estrongilídeos e coccídios pela quantificação (média $\pm E P$ ) de ovos e oocistos. Os dados de prevalência foram comparados pelo teste Qui-quadrado, intensidade da infecção (média $\pm E P$ ) pelo teste Scott-Knott (SAEG 9.1), ambos com $P<0,05$. A prevalência geral encontrada foi de $77,6 \%$, para estrongilídeos foi $64,15 \%$, coccídios 36,2\% e cestódeos (Moniezia sp.) 8,81\%. As ovelhas solteiras apresentaram a menor prevalência (52,5\%), já os cordeiros apresentaram 95,5\%, não diferindo das demais $(P<0,05)$. Quanto a intensidade da infecção por verminoses por nematódeos, os cordeiros apresentaram OPG mais elevado versus ovelhas solteiras $1297 \pm 270$ vs. $232 \pm 79$, respectivamente. As categorias ovelhas paridas, solteiras e reprodutores apresentaram média de OPG abaixo do que é indicado para tratamento com fármacos. A

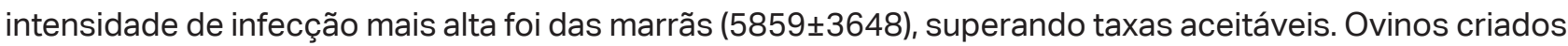
em Sena Madureira apresentam alta prevalência para verminose por estrongilídeos, baixas prevalências para coccidiose e cestodioses. Categorias animais jovens apresentam elevado risco sanitário para as endoparasitoses, devendo-se adotar medidas de manejo que colaborem com a profilaxia e controle dessas enfermidades.

Palavras-chave: Eimeriose. OPG. Parasitismo. Verminose.

\section{Introduction}

Sheep farming is an activity of the agricultural sector explored across the continent, playing a very important role in the economy. Beef sheep farming has become an activity increasingly attractive for the diversification of agricultural production due to the growing demand for sheep meat (Silva et al., 2011b).

The Brazilian sheep herd was 19.7 million heads in 2019. Beef sheep farming in the Northeast region of Brazil, where about $68 \%$ of the sheep herd is concentrated, contributes to a prominent role in the activity in national livestock (Instituto Brasileiro de Geografia e Estatística [IBGE], 2019). 
Also, according to the IBGE, the State of Acre, located in the North region, had 86.4 thousand animals in 2019 and the municipality of Sena Madureira, belonging to the Purus region, had a herd of 10.7 million animals.

Gastrointestinal parasites are great obstacles to the increase in the herd and cause serious economic losses, with animal mortality, productivity loss, and frequent use of vermifuges, which leads to parasite resistance to anthelmintics. Thus, animals with high parasitic levels may lose a large amount of blood, developing a picture of severe anemia in a short time (Mexia et al., 2011).

Eimeriosis, also known as coccidiosis, is an important parasitic disease caused by protozoa of the family Eimeriidae, genus Eimeria (Martins et al., 2020). It is a parasitic disease of worldwide distribution and mainly affects young sheep raised under different management systems (Lopes et al., 2013).

The following nematodes affect sheep and present greater economic importance because they have a higher intensity of infectionandahigher prevalence:Haemonchus contortus, Trichostrongylus colubriformis, Strongyloides papillosus, Trichostrongylus axei, Trichostrongylus colubriformis, Cooperia sp., Bunostomum trigonocephalum, Oesophagostomum columbianum, Trichuris ovis, Trichuris globulosa, and Skrjabinema sp. (Roberto, Difante, Zaros \& Gurgel, 2018).

Although there is no doubt among researchers, technicians, and producers that verminosis is a serious problem for small ruminants, losses related to productivity have not been well quantified. Therefore, the evaluation of the effectiveness of anthelmintics allows appropriate management strategies to be put into practice, leading to lower losses (Costa, Costa, Mendonça, \& Vaz, 2017).

In this sense, this study aimed to understand the epidemiology of the main gastrointestinal endoparasites affecting sheep raised in the municipality of Sena Madureira, Acre, Brazil.

\section{Material and Methods}

This study was carried out on ten farms in the municipality of Sena Madureira, southwest of the Western Amazon, Brazil, at $144 \mathrm{~km}$ from the capital Rio Branco, State of Acre. The municipality has an area of $23,753,067 \mathrm{~km} 2$, which is equivalent to $16.62 \%$ of the total area of the State, an estimated population in 2018 of 43,139 inhabitants, and a demographic density of 1.60 inhabitants/ $\mathrm{km}^{2}$ (IBGE, 2018). It is located at the geographic coordinates $09^{\circ} 03^{\prime} 57^{\prime \prime} \mathrm{S}$ and $68^{\circ} 39^{\prime} 25^{\prime \prime} \mathrm{W}$, with an altitude of $150 \mathrm{~m}$ above sea level.

The region has a tropical climate according to the Köppen classification. The temperatures vary from 20 to $33{ }^{\circ} \mathrm{C}$ throughout the year, with values rarely below $13^{\circ} \mathrm{C}$ or above $33^{\circ} \mathrm{C}$ (Weather Spark, 2018), an average annual temperature of $24.8^{\circ} \mathrm{C}$, and an average annual precipitation of $2,017 \mathrm{~mm}$ concentrated between November and April.

This study was not submitted for evaluation to the Ethics Committee of the Federal Institute of Education, Science and Technology of Acre, campus of Sena Madureira and we are aware of the content of the resolutions of the National Council for the Control of Animal Experimentation (CONCEA), available at https://www.unifalmg. edu.br/ceua/system/files/imce/Diruntas_ CONCEA23Maio2013.pdf. 
The samples were collected from May to November 2017 in herds formed by mixed breed sheep raised in an extensive system, with animals sheltered in sheepfolds on the ground or with raised slatted floors.

The number of samples per farm was defined according to the herd size and the animal categories, that is, ewe lambs, ram lambs, rams, lambing ewes, and ewes (without lambs at the foot), ensuring the representativeness of the sample. A total of 20 to $30 \%$ of animals per category was considered in the sample size, except for rams, which were $100 \%$ evaluated.

Procedure gloves were used to collect fecal samples directly from the animals' rectal ampoules, being wrapped in individually identified plastic bags, packed with reusable ice in isothermal boxes, and transported to the Laboratory of Multidisciplinary Biology at the Federal Institute of Education, Science and Technology of Acre (IFAC), campus of Sena Madureira, for laboratory analysis.

\section{Parasitological examinations} were conducted within 48 hours after sample collection. Feces were processed individually and evaluated using the flotation technique in saturated saline solution. Positive samples were submitted to the macroscopic examination and processed by routine helminthology methods, i.e., the number of eggs per gram of feces (EGF). The Gordin and Whitlock technique was used through McMaster chambers to perform the counting of eggs and oocysts, allowing the quantification of oocysts of the genus Eimeria sp. and nematode eggs of the genus Strongylus sp. and the family Strongylinae, but without identifying the genera/species, according to Ueno \& Gonçalves (1998).
The EGF data were subjected to the normality test, transformed into $\log ^{10}$, and then compared by the Scott-Knott test (SAEG 9.1), considering the effect of the animal categories. The prevalence data taken as a percentage were compared by the chi-square test.

\section{Results and Discussion}

A total of 178 fecal samples (Table 1) were analyzed for the quantification and possible identification of different gastrointestinal endoparasites (nematodes, trematodes, and coccidia), reaching an overall prevalence of $77.6 \%$ (137/178). All farms had positive samples for some parasites. Helmer., et al. (2020) found the occurrence of gastrointestinal parasites in $90 \%$ of the farms in the microregion of Castanhal, Pará, Brazil.

Oliveira, Silva and Ribeiro (2019) observed the status of gastrointestinal parasites in a herd of sheep in the state of Rondônia, Brazil, and diagnosed the presence of helminths of the genera Haemonchus, Strongyloides, and Trichostrongylus.

The prevalence was $64.15 \%$ for nematodes, $36.2 \%$ for coccids, and $8.81 \%$ for trematodes (Moniezia sp.) (Tables 2 and 3).

Unlike other animal husbandries, it is not uncommon to find parasitism in the digestive tract of ruminants due to their food source (forages) and eating habits (grazing), constantly re-contaminated. However, sheep developed efficient immune mechanisms after their domestication process (one of the first species to be domesticated), allowing them to tolerate parasitism at low levels. 
Table 1

Scores for clinical and laboratory parameters in 24 dogs with CKD according with the predominant glomerular injury

\begin{tabular}{|ccc|}
\hline Category & $\mathrm{N}$ & Prevalence (\%) \\
\hline Rams & 10 & $90.0^{\mathrm{A}}$ \\
\hline Lambing ewes & 37 & $81.1^{\mathrm{A}}$ \\
Ewes & 40 & $52.5^{\mathrm{B}}$ \\
Ewe lambs & 46 & $76.1^{\mathrm{A}}$ \\
Ram lambs & 45 & $95.5^{\mathrm{A}}$ \\
Total & 178 & 77.8 \\
\hline
\end{tabular}

A,B Values followed by different uppercase letters in the same column differ from each other by the chi-square test $(P<0.05)$.

Regarding the influence of the categories on the prevalence of endoparasites, ewes, in general, had a lower prevalence rate than the other categories $(P<0.05)$. In this sense, apparently, this category presented the most efficient immunity condition in the fight against parasitism. Age, nutritional status, and physiological transitions have a major influence on susceptibility, and stages that require more nutrients, mainly aimed at production, show a higher incidence (Silveira, Brondani, Motta, Ferreira \& Lemes, 2015).

Some physiological stages of animals exert negative pressure on the immune response, such as females in the prepartum and postpartum period, breeding animals in the field, and young animals with immature immune systems. Lambing females or even in the last third of gestation show a weakened immune system due to fetal growth, which increases the demand for nutrients, while diet intake is, to a large extent, intended for lambs. Therefore, protein supply to the immune system may decrease, making the female sheep in this condition more sensitive to verminoses.
Younger categories such as ewe lambs and pre-weaning lambs, in addition to still having a maturing immune system, may still be in the intake transition period for pasture, which favors contamination by parasites, as animals are highly susceptible to verminosis until puberty (Mexia et al., 2011).

A study with lambs found the presence of the first oocysts of Eimeria spp. at the 3rd week of age, a peak of oocysts at the 6th week, with all the animals showing high levels of infection, followed by a spontaneous and gradual retreat of the count, and some lambs stopped eliminating oocysts or eliminated them at low quantities at the 10th week of age (Silva, Facury, Souza, \& Ribeiro 2011a).

The level of infection with strongylid nematodes showed that animal categories influenced the means of EGF, with lambs having the highest count and ewes the lowest count, with values of $1297 \pm 270$ and $232 \pm 79$, respectively (Table 2 ). In this sense, Gomes et al. (2011) conducted a study in the municipality of Araguatins, Tocantins, Brazil, aiming to register the parasitic nematode load and verify the presence of Eimeria spp. in sheep 
and observed that young males were more infected by strongylids than females. However, the literature also shows that adult animals can present high levels of verminoses when under challenging physiological situations such as breeding or lambing seasons (Silva et al., 2010).

Moreover, the measure of data dispersion (standard error) was high in all categories of sheep. It is possibly due to the fact that there have been some animals within each category with higher parasitic susceptibility, as the immune responses against reinfection develop slowly and incompletely, leaving herds subject to the recurrence of this parasitosis (Vieira et al., 2010).
Animal categories lambing ewes, ewes, and rams presented an average EGF below the recommended for vermifuge treatment, that is, when the egg count per gram of feces is equal to or higher than 500 per sample (Ueno \& Gonçalves, 1998). This result indicates that the animals probably have immunological mechanisms that make it possible to keep the endoparasite population under control.

Only $8.81 \%$ of the animals were infected by Moniezia sp. Lambs had a considerable incidence $(22.2 \%)$, while the other categories showed rates $\leq 10 \%$ (Table 2 ).

\section{Table 2}

Level of infection with helminth in different categories of sheep raised in an extensive system in the municipality of Sena Madureira, Acre, Brazil

\begin{tabular}{cccccc}
\multirow{2}{*}{ Category } & $\mathrm{N}$ & \multicolumn{2}{c}{ Strongyloidea } & \multicolumn{2}{c|}{ Moniezia spp.* } \\
\cline { 2 - 5 } & & Mean \pm SD & $\%$ & 1 & $\%$ \\
Rams & 10 & $660 \pm 219 \mathrm{~b}$ & 60 & 0 & 10 \\
Lambing ewes & 37 & $486 \pm 152 \mathrm{~b}$ & 59.46 & 3 & 0 \\
Ewes & 40 & $232 \pm 79 \mathrm{c}$ & 45 & 2 & 7.5 \\
Ewe lambs & 46 & $443 \pm 117 \mathrm{~b}$ & 65.2 & 10 & 4.4 \\
Ram lambs & 45 & $1297 \pm 270 \mathrm{a}$ & 91.1 & 17 & 22.2 \\
TOTAL & 178 & $636 \pm 88$ & 64.15 & 8.81
\end{tabular}

a.b Values followed by different lowercase letters in the same column differ from each other by the Scott-Knott test $(\mathrm{P}<0.05)$. ${ }^{*}$ Values presented as the number of positive samples/total of samples.

All categories of sheep raised in an extensive system showed infection by Eimeria sp. (Table 3). It corroborates with Oliveira et al. (2019), who found oocysts of Eimeria spp. in all evaluated animals.

This prevalence rate in lambs is a health risk due to the pathogenic potential of cestodes because animals can be carriers of the parasite and eliminate proglottids in the feces.

Additionally, the clinical and zootechnical condition of herds may be greatly aggravated when it is found that parasitic infections in ruminants have a mixed 
character, in which various etiological agents may be simultaneously exerting pathogenic effects, compromising the health of the herd.

Regarding the level of infection by Eimeria sp., younger categories (ewe lambs and ram lambs) had higher means of oocysts than adult categories (Table 3). Gomes et al. (2011) found that $86.67 \%$ of the 30 fecal samples of sheep had eggs from Eimeria sp., and young females showed higher parasitism.
Lopes et al. (2013) identified Eimeria spp. in young and adult sheep raised in intensive and/or semi-intensive systems and found a prevalence of $70 \%$. Comparatively, the prevalence reached $36.2 \%$ in this study (Table 3), showing that the raising system is an essential factor in the contamination of animals, as intensive and semi-intensive systems present a higher infection of animals due to the ingestion of oocysts sporulated next to water and food contaminated with feces.

\section{Table 3}

Level of infection by Eimeria sp. in different categories of sheep raised in an extensive system in the municipality of Sena Madureira, Acre, Brazil

\begin{tabular}{|c|c|c|c|}
\hline \multirow{2}{*}{ Category } & \multirow{2}{*}{$\mathrm{N}$} & \multicolumn{2}{|c|}{ Eimeria sp. } \\
\hline & & Mean \pm SD & $\%$ \\
\hline Rams & 10 & $30 \pm 22^{c}$ & 20 \\
\hline Lambing ewes & 37 & $108 \pm 37^{b c}$ & 35 \\
\hline Ewes & 40 & $46 \pm 19^{c}$ & 25 \\
\hline Ewe lambs & 46 & $5859 \pm 3648^{a}$ & 45.65 \\
\hline Ram lambs & 45 & $728 \pm 270^{b}$ & 55.55 \\
\hline Total & 178 & $1766 \pm 976$ & 36.2 \\
\hline
\end{tabular}

a,bValues followed by different lowercase letters in the same column differ from each other by the Scott-Knott test $(P<0.05)$.

The extensive sheep raising system was predominant among the interviewed farmers. In this context, the low stocking rate of sheep reduces the infestation of parasites in the pasture, the high regional temperature at the time of the year in which the collections were performed can quickly dry out the feces, mainly when they are exposed to the sun, with temperatures above $30{ }^{\circ} \mathrm{C}$, causing a faster development, which leads the larvae to become hyperkinetic and consume their reserves quickly and die more quickly, especially L1 and L2, which are highly vulnerable. Sheep farming associated with cattle is a challenge for the parasite because the larvae of parasites from goats and sheep that may be ingested by other species may be destroyed in the gastrointestinal tract (Costa, Simões, \& Riet-Correa, 2011).

The occurrence of endoparasites is very variable and depends on factors such as food conditions, rainfall, relative humidity, temperature, topography, pasture, time of year, and solar radiation, especially during pregnancy (Chiebao \& Romaldini, 2017). 
Overall, high temperatures and low humidity are harmful to the development and transmission of infectious stages (Gomes et al., 2011). Thus, the ideal temperature for the development of eggs and larvae ranges from 22 to $28{ }^{\circ} \mathrm{C}$ and humidity above $80 \%$ (Silva et al., 2011b).

The larvae can survive for long periods in the low parts of the vegetation, that is, close to the soil, where the humidity and temperature are more or less constant. However, the high precipitation and torrential rains that fall on the region of Sena Madureira, State of Acre, probably carry many of the eggs of the parasites to the nearest streams.

The animals used in this study had good nutrition, as pastures that can meet their daily requirements are available throughout the year. Well-nourished animals naturally have parasitic resistance. On the contrary, animals that receive low nutritional quality food, especially crude protein, are more vulnerable to parasitism because they are unable to develop an immune response capable of preventing infection (Minho, 2014).

The ability of sheep to acquire and express immunity against the action of gastrointestinal nematodes is genetically controlled and varies substantially between different breeds and between individuals of the same breed (Silveira et al., 2015).

\section{Conclusion}

Sheep managed extensively in the municipality of Sena Madureira, Acre, Brazil, showed a high prevalence for strongylids and low prevalence for cestodiasis and coccidiosis, thus demonstrating how these parasites are distributed in the herds.
Young animals, rams, and lambing ewes showed a high pressure of parasitic infection, demonstrating health risk and signaling possible losses that may already be affecting the zootechnical indices of the herds.

Sheep farmers are required to adopt sanitary and reproductive management measures that favor prophylaxis and control of parasites, especially in young animals, avoiding higher economic losses in the activity.

\section{References}

Chiebao, D. P., \& Romaldini, A. H. C. N. (2017). Boletim técnico-sanidade na ovinocultura II. São Paulo: SP: Instituto Biológico.

Costa, P. T., Costa, R. T., Mendonça, G., \&, Vaz, R. Z. (2017). Eficácia anti-helmíntica comparativa do nitroxinil, levamisol, closantel, moxidectina e fenbendazole no controle parasitário em ovinos. Boletim de Industria Animal, 74(1), 72-78. doi: 10.17523/bia.v74n1p72

Costa, V. M. M., Simões, V. D., \& Riet-Correa, F. (2011). Controle das parasitoses gastrintestinais em ovinos e caprinos na região semiárida do Nordeste do Brasil. Pesquisa Veterinária Brasileira, 31(1), 6571. doi: 10.1590/S0100-736X201100010 0010

Gomes, W. M., Alencar, R. D. R., Machado, D. L., Silva, R. S. da, Silva, K. C. C. da, \& Vargas, C. R (2011). Parasitos gastrointestinais encontrados em ovinos no município de Araguatins-TO. Revista Agroecossistemas, 3(1), 68-72. doi: 10. 18542/ragros.v3i1.1373

Helmer, J. F., Oliveira, C. A., Cerqueira, V. D., Bezerra, P. S., Prado, R. G. S., Pires, C. R. S., 
\& Riet-Correa, G. (2020). Caracterização dos sistemas de produção de ovinos e caprinos na microrregião de Castanhal, Pará. Medicina Veterinária (UFRPE), 14(3), 202-209. doi: 10.26605/medvetv14n3-3862

Instituto Brasileiro de Geografia e Estatística (2018). Pesquisa de Pecuária Municipal: efetivo do rebanho. Recuperado de https://cidades.ibge.gov.br/brasil/ac/ pesquisa/18/16459

Instituto Brasileiro de Geografia e Estatística (2019). Pesquisa da Agropecuária Municipal. Recuperado de https://sidra. ibge.gov.br/tabela/3939

Lopes, W. D. Z., Borges, F. A., Faiollai, T. P., Antunes, L. T., Borges, D. G. L, Rodriguez, F. S., Martinez, A. C. (2013). Eimeria species in young and adult sheep raised under intensive and / or semi-intensive systems of a herd from Umuarama city, Parana State, Brazil. Ciência Rural, 43(11), 2031-2036. doi: 10.1590/S010384782013001100018

Martins, N. S., Motta, S. P. da, Santos, C. C. dos, Moreira, A. S., Farias, N. A. R., \& Ruas, J. L. (2020). Eimeriose em bovinos e ovinos:uma inimiga invisível. Brazilian Journal of Development. 6(4), 1942119434. doi: 10.34117/bjdv6n4-201

Mexia, A. A., Macedo, F. A. de, Oliveira, C. A. L de, Zundt, M., Yamamoto, S. M., Santello, G. A.,.Sasa, A. (2011). Susceptibilidade a nematóides em ovelhas Santa Inês, Bergamácia e Texel no Noroeste do Paraná. Semina: Ciências Agrárias, 32(1), 1921-1928. doi: 10.5433/1679-0359.2011v32Suplp1921
Minho, A. P. (2014). Endoparasitoses de ovinos: conhecer para combater. (Circular Técnica, 45). Bagé, RS: EMBRAPA Pecuária Sul. Recuperado de https://www.infoteca. cnptia.embrapa.br/infoteca/bitstream/ doc/991015/1/CiT4514online.pdf

Oliveira, R. S. de, Silva, A. M. da, \& Ribeiro, F. L. A. (2019). Status de parasitas gastrintestinais em ovinos no estado de Rondônia. Revista Brasileira de Higiene e Sanidade Animal, 13(3), 401-410.

Roberto, F. F. S., Difante, G. S., Zaros, L. G., \& Gurgel, A. L. C. (2018). Nematoides gastrintestinais na ovinocultura de corte sob regime de pastejo. Publicações em Medicina Veterinária e ZootecniaPUBVET, 12(4), 1-12. doi: 10.22256/pub vet.v12n4a65.1-12

Silva, M. R. L. da, Souza, E. A. de, Bonelli, E. A., Medeiros, M. O., Silva, G. F. da, \& Queiroz, E. O. (2010). Parasitas gastrintestinais de ovinos criados na região de Rondonópolis - MT. Revista Biodiversidade, 9(1), 67.

Silva, R. M. da, Facury, E. J., Fo., Souza, M. F., \& Ribeiro, M. F. B. (2011a). Natural infection by Eimeria spp. in a cohort of lambs raised extensively in Northeast Brazil. Revista Brasileira de Parasitologia Veterinária. 20(2), 134-139. doi: 10.1590/S1984-2961 2011000200008

Silva, S. C. da, Mexia, A. A., Garcia, J., Souza, O. M. de, Botini, T., Silva, G. M. A.,... Gomes, L. A. (2011b). Verminose em rebanhos ovinos. Publicações em Medicina Veterinária e Zootecnia- PUBVET, 5(1), 902-998.

Silveira, F. A., Brondani, W. C., Motta, J. F., Ferreira, O. G. L., \& Lemes, J. S. (2015). Resistência ovina frente a nematoides gastrintestinais. Archivos de Zootecnia, 64(R), 1-12. doi: 10.21071/az.v64i247.501 
Ueno, H., \& Gonçalves, P. C. (1998). Manual para o diagnóstico das helmintoses de ruminantes. Tokyo: Japan Internatinal Cooperation Agency.

Vieira, L. da S., Lobo, R. N. B., Cavalcante, A. C.R., Navarro, A. M. do C., Benvenuti, C. L., Neves, M. R. M., \& Zaros, L. G. (2010). Panorama do controle de endoparasitoses em pequenos ruminantes. Cidade:Sobral' $\mathrm{CE}$. EMBRAPA Caprinos e Ovinos.
Weather Spark (2018). Condições meteorológicas média de Sena Madureira. Recuperado de https://pt.weat herspark.com/y/27357/Clima-caracter $\%$ C3\%ADstico-em-SenaMadureiraBrasil-durante-o-ano 